\title{
Age, Gender and Feminism: Addressing the Gap from Literary and Cultural Perspectives
}

\section{leva Stončikaitè}

\begin{abstract}
Although important demographic shifts have generated both an interest and profound transformations in sociocultural interpretations of ageing and old age, the experience of growing older is still perceived negatively and is often measured according to how successfully people adapt to the current Western ideals of later life. In the light of recent research on cultural and literary representations of ageing, this article critically addresses contemporary American writer Erica Jong's mid-life and later works from feminist and gender perspectives. It shows how the author's writings contest the narrative of decline and ageism and incorporate some aspects of positive ageing in terms of body image. Yet, instead of following the model of successful ageing, Jong offers alternative views of ageing femininities and sexuality that enable a different narrative of growing older to emerge. The writer's work also shows that socially and culturally constructed gender and power relationships can be deconstructed, which allows for new forms of self-expression that are not moulded into antiageing discourses and their neoliberal imperatives.
\end{abstract}

Keywords: ageing, gender, feminism

Stončikaitè, leva. 2021. Age, Gender and Feminism: Addressing the Gap from Literary and Cultural Perspectives. Gender a výzkum / Gender and Research 22 (1): 59-77, http://dx.doi.org/10.13060/gav.2021.012.

A longer life course and rapidly changing demographic shifts have generated profound transformations in social, political, and cultural interpretations of ageing and later life (Gilleard, Higgs 2014; WHO 2018). These important changes have also contributed to a growing interest in interdisciplinary and critical approaches to the process of growing older, which includes but also goes beyond the traditional field of gerontology (Blaikie 1999; Calasanti, King 2015; Gilleard, Higgs 2014; Marshall, Katz 2012; Twigg, Martin 2014). The greater attention given to the realities and challenges of ageing has propelled the emergence of cultural and literary gerontology, which extends gerontological frameworks by analysing ageing through the lens of intersectionality 


\section{STATI / ARTICLES}

and critical standpoints and offers a more meaningful view of gender relationships and the multifaceted experience of ageing. Critical age-related approaches to literary texts also help reveal that ageing, often portrayed by the persistent narrative of decline (Gullette 2004) and the double standard of ageing (Sontag 1972) in Western societies is, in fact, a dynamic process marked by continuity and a journey inwards (Baars 2012; Barry, Vibe Skagen 2020; Casado-Gual, Domínguez, Worsfold 2016; Cohen-Shalev 2008; de Medeiros 2016; Gullette 2004, 2011; Hepworth 2000; Waxman 1990; Wyatt-Brown 2010; Wyatt-Brown, Rossen 1993). Although a literary approach to age-related narratives does not explain the reasons for growing older nor give us answers to questions about old age, it examines what the process of ageing implies culturally, socially, and politically (Kriebernegg 2015). To use Kriebernegg's words, literary gerontology makes it possible to foster 'productive interdisciplinary dialogue on how ageing as a lifelong process is understood and experienced' (2015: 839). At the same time, it provides scholars with significant perspectives for interpreting and comprehending the dynamics of ageing and old age (Zeilig 2011).

As will be shown here, the representations of contemporary female ageing in Erica Jong's work make it possible to dive deeper into the complexities of coming to terms with age in relation to gender, body politics, and intimacy. By employing critical literary analysis, and by integrating feminist and gender perspectives in it, this article draws upon selected scenes from Jong's middle and later-life writings ${ }^{1}$ that demonstrate how the author contests the narrative of decline and incorporates some aspects of successful ageing. Yet, at the same time, her writings do not follow the ideals of positive ageing. Instead, Jong enables the development of a different narrative of growing older that goes beyond the dominant Western age-related discourses and challenges a gender-specific representation of old age. Her position as a spokeswoman of the American post-war cohort is especially relevant, given that the women of her generation are now approaching their latest stages in life and, therefore, are exposed to new challenges within the context of controversial antiageing imperatives.

In fact, since the publication of her bestselling book, Fear of Flying (1973), the author has never ceased to explore her cohort's emotional, professional, and sexual needs. Although Fear of Flying was a revealing book for many women during Second-Wave feminism and the sexual revolution of the 1970s, Jong's tendency to incorporate sexual female experiences mixed with humour and wit has generated a lot of controversy,

\footnotetext{
1 This article focuses on Jong's mid-life works Fear of Fifty (1994) and What Do Women Want? (1999) and her later-life writings Seducing the Demon (2006) and Fear of Dying (2015). The author is grateful to the reviewers for their valuable comments, which helped improve the manuscript.
} 
thus denigrating her career as a woman writer (Templin 1995, 2002). Although criticised, the author has continued to voice professional, intimate, and personal fears and anxieties that concern women of her generation (Templin 1995, 2002). In her midlife memoirs and other later writings, which are often autobiographical in nature, she reveals important aspects about the conflicting and, at the same time, enriching experience of female ageing and that of being an older woman in contemporary society. An age-, gender-, and feminist-studies approach to Jong's later writings contributes to a better understanding of the sociocultural significance of her work, and shows important, but often silenced, aspects of female identity that have not been sufficiently addressed. Her works also help address the gaps that represent the lack of dialogue, reflections, and insights about how feminist critiques and gendered Western ageing norms have not adapted to our rapidly ageing society. A deeper reflection on the author's later writings reveals alternative perspectives from which to view the process of ageing for white, middle-aged, and often well-off women, who are also Jong's targeted audience.

The following sections draw from various literary and scientific sources to explore how the process of ageing and its psychological, sociocultural, and physical complexities intersect with gender and feminism. They identify key messages from early feminist writings and long-standing cultural notions about successful ageing along with its neoliberal imperatives and the double standard of ageing (Sontag 1972), which reveals that older women face more pressures than men because of the loss of sexual and physical attractiveness. Sontag's argument of the double standard of ageing shows how appearance-related disadvantages have harsher consequences for ageing women, and lead to a double categorisation and discrimination based on gender inequality and ageism.

\section{Feminist and gender approaches to age(ing) studies}

Female ageing realities reflected in literary texts would be incomplete without feminist and gender scholarship. As gerontologist Toni Calasanti highlights, feminism 'gives us the tools to examine ageism and age relations more deeply' (2004: 7). Feminist scholars, concerned with the double marginalisation that both ageing and gender imply, were the first to problematise ageing in literary age studies (Barry, Vibe Skagen 2020). The growing visibility of the feminist input in ageing studies is evident in the expansion of topics, methods, and new areas of study that provide feminist scholars with new vantage points from which to reflect not only on the political, social, cultural, and historical implications of ageing, but also on their own ageing experiences (Calasanti 2004). In recent decades, there has been a notable growth of literary works that critically look into the ways in which age is represented in relation 
to broader topics that concern women today (Barry, Vibe Skagen 2020). The depiction of older women's experiences has become more emphasised because the generation of feminists who were active during the 1960s and 1970s have gone through their midlife crises, and thus have become more interested in defending their rights and privileges, determining their roles, and changing the stigmatisation of older women (King 2013).

Simone de Beauvoir's The Coming of Age (1972) (first published in French under the title La Vieillesse in 1970) is one of the first texts to voice the concerns of ageing women and show their marginalised position as discriminated 'Others.' According to de Beauvoir, women have always been victims of sexual and gender inequality. In her book, the writer argued that even though midlife and older age could be seen as liberating stages that exempt women from social obligations, family burdens, and the patriarchal order, they are not fulfilling because those freedoms can no longer be used to women's own benefit. According to the author, growing older makes women less visible and more neglected in society in comparison to men. Even though de Beauvoir highlighted the concerns of ageing women in her work, it did not receive much attention and interest from Second-Wave activists. In fact, the feminist positioning of ageing women as victims has strengthened the associations of older women as frail and in need of protection. Although Susan Sontag addressed the negative connotations ascribed to ageing women in her famous article The Double Standard of Aging (1972), it was not until the 1990s and beyond that age-related issues became more pronounced in the feminist agenda.

The feminist writer Germaine Greer saw the need to empower ageing women as a way to fight patriarchy and ageism. In The Change: Women, Ageing and the Menopause (1991), Greer observed that as a woman grows older, she becomes more satisfied with herself and her inner being. A post/menopausal woman embodies invisibility and freedom from sexual objectification, which allows her to get closer to her true self. To Greer, old age is not a time of crisis for a woman but is rather an autumn that is 'long, golden, milder and warmer than summer, and is the most productive season of the year' (1991: 142). Similarly, the feminist author Carolyn Heilbrun celebrated the midlife stage for women and called it the 'magic circle of invisibility' that leads to 'the land of new accomplishment and new passion' (1991: 27). According to these pioneering feminist scholars, reaching older age is a turning point in life because it coincides with the onset of menopause and thus the end of the reproductive life course, which grants women more freedom and allows them to get closer to their true selves.

However, although the notion that older women may feel liberated as they are freed from the ubiquitous patriarchal control over their bodies and the male gaze may be true for some women, this view does not challenge or subvert the already 
established sexist and ageist ideas towards older women today. Ageing women continue to be socially stigmatised, marginalised and discriminated, which shows the persistence of ageism, sexism, gender inequality and the double standard of ageing. Betty Friedan, along with other feminist writers, has pointed to the importance of giving a voice to ageing women. In her work The Fountain of Age (1993), Friedan examined practical issues that concern older women and called for the reconsideration of the negative stereotyped meanings that are attributed to older age. Margaret Morganroth Gullette is among the first age critics to challenge negative connotations about ageing women, biological essentialism, and ageism in Western cultures. She also noted that age-related stereotypes are often coded into a narrative of decline, according to which ageing women are perceived as frail, asexual, and dependant (2004). Other feminist gerontologists, such as Toni Calasanti and Kathleen Slevin (2001), have suggested including a consideration of age, along with race, class, and gender, as a social category that is inextricably linked to social inequalities, power relations, and ageism. In their view, traditional feminist theory has not considered age-based relations and social structures that create long-lasting effects on older women and limit opportunities in later life. Additionally, these scholars argued that the discourse of successful ageing has also greatly conditioned ageing women's freedom and their experiences of ageing by stressing women's bodily image and sexuality. In her later works, Erica Jong also examines contemporary female ageing realities and depicts the increasing emphasis on rejuvenation and active sexual lives in later years. As will be demonstrated, the critical use of literary gerontology helps better illustrate how Jong's writings challenge and connect with gendered and ageist attitudes about later life and notions of positive ageing.

\section{Gendered ageing female bodies in Jong's later work}

Erica Jong's later work and her personal accounts resonate with gender-sensitive research on ageing, as both the writer and her fictional characters fall prey to the discourse of successful ageing. Originating in the United States in the second half of the 20th century, this anti-ageing ideal was defined in the works of social scientists John Rowe and Robert Kahn (1987, 1998), who focused on three main standards of ageing that emphasised the avoidance of disease and disability, high levels of cognitive and physical functioning, and active social engagement. Rowe and Kahn also highlighted that ageing successfully was an individual's own responsibility: '[o]ur main message is that we can have a dramatic impact on our own success or failure in ageing. Far more than is usually assumed, successful ageing is in our own hands' (1998: 18). In other words, the main idea behind the model of successful ageing is that as long as people keep an eye on their physical and mental wellbeing 
and enthusiastically participate in social circles and leisure activities, they are ageing gracefully (Blaikie 1999; Calasanti 2016; Gilleard, Higgs 2014; Katz 2000; Katz, Calasanti 2015; Marshall, Katz 2012; Martinson, Berridge 2015; Timonen 2016; Twigg, Martin 2015; Vincent, Phillipson, Downs 2006). Yet, and very importantly, older people are in charge of their own 'success' in later life. As Calasanti and King state, '[s]uccessful ageing means not ageing and not being old because our constructions of old age contain no positive content' (2005: 7). The successful ageing discourse, closely intersected with neoliberal rationality and capitalist ideology, has imposed new ways on ageing and divided older people into two categories: winners and losers (Strawbridge, Wallhagen 2002). However, Rowe and Kahn's defined model of success in later life continues to be present in today's society and is now a significant part of Western thought, politics, research, media, social relations, lifestyles, healthcare, and the anti-ageing industry (Calasanti 2016; Gilleard, Higgs 2014; Katz 2000; Katz, Calasanti 2015; Marshall, Katz 2012; Timonen 2016). As age scholar Stephen Katz observes, this discourse is so integrated into how the wellbeing of older adults and their lifestyles is measured that to question it 'would be considered unprofessional, if not heretical' (2000: 135). Along with the emergence of the discourse of successful ageing, age-related norms and behaviour patterns have become more flexible and blurred (Blaikie 1999; Gilleard, Higgs 2014; Marshall, Katz 2012). These changes are especially visible in the treatment of the body and sexuality in later life, the tropes that are recurrent in Jong's later writings.

Anxieties about physical attractiveness are visible in Jong's works, in which she reflects on gendered attitudes towards female bodily changes and their stigmatisation in youth- and beauty-obsessed Western society. Although in her early writings Jong was already expressing worries about her outward appearance and a desire to adapt her body to the beauty ideals of femininity and desirability, the concerns about her body became more pronounced as she entered the second half of her life (Stončikaite 2019). In her midlife memoir Fear of Fifty (1994), Jong writes that as a woman grows older, almost every birthday becomes a turning point in her life, one that further reduces her visibility and desirability. Reaching midlife also coincides with the biological marker of menopause, which symbolises the end of a woman's reproductive life (Heilbrun 1991; Greer 1991; Woodward 1999). Although the feminist writers mentioned above have argued that midlife is a liberating stage in life for a woman, since it grants her invisibility and freedom from the male gaze, Jong, as will be shown, does not follow this thought in terms of older women's sexuality. The author argues that as women grow older and their bodies become more unforgiving and less socially acceptable, they become not only less visible, but even feared in society, which reveals ageism, gendered inequalities, and the double standard of ageing. In one interview, Jong, at the age of seventy-three, stated that '[a]s women, we can't look old. We can't be 
fat. We're supposed to look like the 14-year-old models in Vogue, who are younger and younger and skinnier and skinnier, and they are air-brushed and contoured and Photoshopped' (Burns 2015: n/p).

For instance, in the latest novel to date, Fear of Dying (2015), Jong's heroine Vanessa expresses her envy for younger women and confesses that she did not know how to appreciate her youth when she still had it. The protagonist is so ashamed and unhappy with her ageing body and the loss of her youthful charms that she would even abandon her values or morals if it meant she could regain her youthfulness and beauty: 'I hate, hate, hate getting older. I would sell my soul to the devil to stay young' (Jong 2015: 151, emphasis in original). Vanessa, like Jong herself, struggles to accept her ageing body and cannot reconcile her still youthful inner self with her ageing physical body. Instead of providing a sense of liberation and freedom in later life, the ageing body seems like a 'betrayal of the youthfulness of the inner self', and thus becomes a threat to a woman's identity and self-worth (Öberg 2003: 106). Jong's inner frustrations and troubled feelings indicate the mismatch between her external appearance and the inner perception of the self, which closely relate to the 'mask of ageing', a term coined by Featherstone and Hepworth (1989, 1999), which refers to the sense of the younger self that lives within an older body and to which a younger self-identity is bound.

In order to achieve congruence between one's inner sense of self and one's outward image, older individuals, especially women, tend to seek solutions in non-surgical cosmetic interventions. The more ashamed women are about their looks and inability to meet the socially defined standards of beauty and success in later years, the more willingly they decide to undergo cosmetic surgery (Henderson-King, Henderson-King 2005; Farshidfar, Dastjerdi, Shahabizadeh 2013; Greer 1991). Woodward observes that the disguised purpose of cosmetic surgery is not to change the bodily image per se, but to correct it and adapt it as much as possible to resemble the youthful model that is represented 'by the aesthetics of smoothness, tact, and good taste' (1991: 162). As Jong and her fictional characters grow older, they become unhappier with their ageing bodies to the extent that their concerns lead them to get a facelift (Stončikaite 2020). They give in to anti-ageing ideals and contemporary Western beauty standards, which reveal how the model of successful ageing and the emphasis on youthful looks have invaded female bodies and even their inner beings. Jong's experiences with life after a facelift are a recurrent theme in her other later works, in which she writes about the worries and uneasiness that arise after the surgical intervention (Stonciikaite 2020). Jong's inability to frown after the operation and the sensation she had that her face has been cut and stretched to adjust it to the ideals of feminine beauty make her feel lifeless and generate guilt and conflicting feelings. The writer cannot find her true self in a newly reshaped face, which lacks the very essence of life: 
I felt like I was dead. I felt like I had entered a bardo between one existence and another. I sat there waiting for my face to heal, waiting to become myself again, to undo the spell I was under. ... I kept expecting to look in the mirror and find another person. However many times I looked, I did not believe what I saw. It was as if I expected a brand to show up on my forehead reading, ' $V$ ' for vanity. (Jong 1999: 62-63)

Jong's literary representations of internal conflicts and struggles related to an ageing body and surgical interventions highlight the cultural constructs of female beauty and the social pressure to adhere to them. Aspirational medicine, innovations in biotechnology, and anti-ageing products spread the message that an ageing body can be reshaped, rejuvenated, and adjusted to social expectations that are based on the ideals of beauty and youth (Bayer 2005; Gilleard, Higgs 2014; Katz 2000; Katz, Gish 2015; Laliberte 2015; Mykytyn 2006; Sandberg 2013; Smirnova 2012; Vincent 2008). The anti-ageing industry in tandem with the pharmaceutical industry and the discourse of successful ageing assure women that the ravages of time can be efficiently effaced from their body with a helping hand from scientific and medical advances. In fact, anti-ageing products and procedures are presented as important remedies that guarantee good health, wellbeing, and quality of life in later years, all of which is associated with the ideals of successful ageing (Calasanti, King 2005; Gilleard, Higgs 2014; Katz 2000; Mykytyn 2006; Smirnova 2012; Timonen 2016). People entering the second half of their lives are instructed that they have a fundamental right to their health and are entitled to "'age better" by "not being old"' (Gilleard, Higgs 2014: 145-146). As Calasanti and King note, we regard the signs of ageing as markers of 'personal goodness' and the '[f]ailure to appear healthy permits others to stigmatize a person as unfit' (2005: 195). The fact that one's exterior body image is considered an extension and an expression of one's personal responsibility, morality, and good will again reveals the existence of neoliberal practices and capitalist interests in the model of successful of ageing (Katz 1996, 2000).

Jong and her fictional characters keep their ageing bodies under constant surveillance, which also shows the ongoing disciplinary power of age, as highlighted in Katz's (1996) Foucaultian study of old age. Jong continues to acknowledge that it is very hard for the women of her generation to find their true selves because consumerist lifestyles and the youthful ideals of beauty influence women's social and individual identities. Although anxieties about bodily decline and the desire to look youthful affect both men and women, bodily changes are more visible on women's bodies and, especially their faces, because of the double standard of ageing (Daniluk 2003; Sontag 1972; Wolf 2002). Higher demands and pressures are placed on women than men to keep their youthful looks and to embody a socially 
and culturally acceptable image, and this is often in turn translated into a sign of desirability, femininity, and sex appeal (Daniluk 2003; Wolf 2002). As Marshall and Katz state, successful ageing expects us to grow older without getting and looking older, which is especially applicable to women 'because of the cultural idealization of their bodies as age-defying technologies' (2012: 224).

\section{Jong's ambivalence and sociocultural constructs}

Although Jong and her fictional characters ultimately decide to yield to social pressure and undergo a surgical intervention in order to keep their youthful looks and adhere to feminine beauty standards, their uneasy feelings and anxieties reveal their criticism of the anti-ageing industry, feminism, and socially constructed Western ideologies. According to the author, the female representatives of the baby-boom generation lack role models and, thus, struggle to come to terms with their inner selves (Stončikaite 2019, 2020). In Fear of Fifty, Jong writes that feminist activists have failed to establish the proper validation of older women and to change what female ageing means. Although women activists of the 1970s challenged gender, racial, and social inequalities, they did not take into account the construction of age and its impact on female identity and the female condition (King 2013). As mentioned previously, even if some feminist writers, such as de Beauvoir, Friedan, and Sontag, addressed the concerns of ageing women, older women were not a priority issue in the feminist agenda in that historical period. Therefore, their worries and needs remained unvoiced and unknown until the 1990s and beyond (King 2013). Jong seems to be trapped in an ongoing paradox: although she criticises the Second-Wave feminist movement that did not address ageism and the double standard of ageing, she struggles to fight the powerful ideologies and image of successful ageing that link morality, personal goodness, and overall success in later life to what a person looks like on the outside (Calasanti, King 2015; Katz 1996, 2000). As she states, 'years of brainwashing are not so easy to forget. The beauty trap is deeper than you thought' (Jong 1994: xviii). Jong's troubled feelings about the ravages of time and her fluctuating position in terms of female desirability and attractiveness reveal that the author's concerns and fears are a product of the sociocultural climate of our times, conditioned and marked by the powerful anti-ageing industry, the lack of role models for ageing women, and the inactivity of the feminist agenda (Stončikaite 2019, 2020). The author and her character's conflicting feelings also reveal the existence of socially constructed ideologies that act in a particular relationship with power and that influence our identity and social roles, which we are encouraged to accept and internalise.

Jong's ambivalent position in terms of gendered ageing body politics can be better understood by looking at French philosopher Louis Althusser's (1971) concept 
of interpellation and feminist scholar Judith Butler's (1990) performativity theory. According to Althusser, interpellation is the process by which ideology, expressed in social and political institutions, influences people's subjective identities, desires, and social interactions. Sociocultural ideas and values call on individuals to believe that their choices are their own and enlist them in the policing of their own everyday lives for capitalist profit, as exemplified in the model of successful ageing and its neoliberal imperatives. Such ideologies operate in invisible but persuasive ways and play a crucial role in constructing an individual's particular place and role in society. Relatedly, in Gender Trouble: Feminism and the Subversion of Identity (1990) Butler applies Althusser's concept of interpellation to signal gendered identities and social construction. Following postmodernist and poststructuralist practices, Butler argues that gender is constructed through repetitive performative acts that are never stable and coherent but are subjected to discourses, societal expectations, and stylised imitations of dominant conventions. By enacting our gendered identities through a variety of acts and expected behaviours, such as adhering to anti-ageing ideals or feminine beauty standards, we make the idea of gender possible, and it is then perceived as natural and, thus, unquestionable. The performance of gendered roles and social conventions creates a sense of subjectivity that seems to be ordinary and free-flowing and gives us a sense of freedom and agency. Butler claims that individuals think that the way they shape their bodies is an individualistic expression of their free will, yet their acts are mere expressions of how they have been influenced by cultural norms. The promotion of the idea that people are not constrained but free to exercise subjective power makes the successful ageing discourse feasible. The anti-ageing industry further confirms gender relations by promoting different youthbased ideals as a sign of wellbeing, happiness, and quality of life in older age. By seeking rejuvenation, Jong and her heroines enact gendered, age-based, and socially constructed roles, and in so doing they reinforce the oppressive status quo and hegemonic social conventions. This applies especially to women, who are expected to 'adorn' themselves to be sexually appealing to the heterosexual male gaze. In fact, according to Butler, the natural body as a material entity does not exist, because all bodies are discursively regulated and adjusted to a set of recurring social rituals and habits that have been going on since our birth. The increasing use of surgical and non-surgical cosmetic interventions makes the anti-ageing practice appear normative and even natural; it thus becomes no longer questionable, like gender itself. Moreover, over time, our cultural creations become our social reality: unquestioned and taken for granted, such notions and modes of life are eventually passed onto other generations through the process of habitualisation (Berger, Luckmann 1991). As sociologists Peter Berger and Thomas Luckmann put it: 
All human activity is subject to habitualization. Any action that is repeated frequently becomes cast into a pattern, which can then be reproduced with an economy of effort and which, ipso facto, is apprehended by its performer as that pattern. Habitualization action further implies that the action in question may be performed again in the future in the same manner and with the same economical effort. (1991: 70-71)

By acting out their gendered identities in accordance with social expectations, Jong and her heroines comply with the societal roles and reinforce the legitimacy of the anti-ageing industry and power relations. A fake sense of subjectivity, agency, and freedom of choice - 'to lift or not to lift?' (Jong 1994: 3) - make the writer and her fictional characters morally accountable for their own ageing, happiness, and health in later life, as is expected in the discourse of positive ageing.

These aspects relate not only to post-reproductive identity and the inevitable physical changes that come with age, but also to sexuality in later life. However, instead of succumbing to powerful ideologies related to sexual activity in older age, Jong offers alternative narratives of sex and sexuality in her later works. In so doing, the author signals that what is constructed can also be deconstructed (Calasanti, Slevin 2011). By providing different notions of sexuality in older age, Jong shows that people can resist being moulded into socially created discourses and negotiate new meanings and different ways of self-expression that may also help uproot ageism and sexism.

\section{Jong's alternative sexual narratives in later life}

In her later works, the writer challenges social constructivism and the narrative of decline (Gullette 2004) and its association with ageist ideologies by showing that older women are not asexual and uninterested in sexual relationships. At the same time, she critically approaches the emphasis on the erectile phallus and heteronormative sexual performativity as signalling health and happiness in older age (Calasanti, King 2005, 2007; Katz, Marshall 2003; Sandberg 2013, 2015; Sandberg, Marshall 2017; Wentzell 2013). Jong thinks that both young and aged men are too obsessed with their phalluses, which they see as a proof of their heteronormative sexuality, masculinity, and virility, which is reflected in the ideals of successful ageing (Stončikaitè 2017).

Although the emphasis on sex has allowed for more freedom of sexual expression for older individuals and challenged the notion of old age as a stage of asexuality, it has also generated confusion among many ageing individuals. The importance assigned to sex in later years of life has created new pathological pressures to conform 
to the new ideals of a good old age (Calasanti, King 2005, 2007; Katz, Marshall 2003; Sandberg 2013, 2015; Sandberg, Marshall 2017; Wentzell 2013). Both older men and women are expected to embody youthful images as closely as possible, be sexually appealing, and be willing to have sex in order to age 'successfully' under the paradigm of positive ageing (Calasanti, King 2005). Those older individuals who cannot adapt to these expectations, suffer from sexual dysfunction, or are not interested in sex may develop a sense of inadequacy or feel excluded or even discriminated against (Calasanti, King 2005; Gilleard, Higgs 2014; Katz, Marshall 2003; Sandberg 2015; Sandberg, Marshall 2017; Wentzell 2013). To solve any sex 'problem', older people are advised to use sex-enhancing tools, such as Viagra or lubricant gels, get a consultation with a sex therapist, or even undergo medical interventions. As Gilleard and Higgs observe, in our modern society, heteronormative sexual expressions are now regarded as 'our social virtues and indicators of emotional physical and mental well-being' (2014: 109). They also state that 'sexual expression became a right to which all are entitled, to the point that those unable to access sexual partners ... are considered to have "unmet needs" that health and social care services should at least consider, if not meet' (2014: 109). The notion of heteronormative sex creates a powerful narrative of a happy old age and excludes queer, inactive, and physically and mentally disabled subjects, which again reveals the gendered inequalities and marginalisation in the current models of positive ageing (Sandberg, Marshall 2017).

In her later work, Jong does not diminish the importance of sexual expression among older men and women; however, she neither follows the ideals of successful ageing nor the notion that asexuality is a means of female liberation for older women and a way for them to find their true self. Instead of celebrating older women's invisibility and the so-called freedom from the male gaze, Jong shows that human sexuality is ageless and complex and, therefore, cannot be conceptualised. She offers her readers different narratives of sex and sexuality that reveal that the human body is an erogenous zone with unlimited possibilities, even in older age (Stončikaitè 2017). Jong's view of expressions of intimacy in later life aligns with the idea that sex is an 'enjoyable, gratifying, and stress-relieving leisure activity' that can become even more satisfying in retirement (Berdychevsky, Nimrod 2017: 232). As people grow older, they have more time to spend together, get closer to each other, and develop a greater sense of emotional stability, shared intimacy, and mutual understanding (Berdychevsky, Nimrod 2017; Butler, Lewis 2002; Roberts, Padgett-Yawn 2001). Additionally, new sexual experiences can help improve quality of life by enhancing a person's sense of happiness and self-esteem and can provide older people with physical health and psychological benefits (Berdychevsky, Nimrod 2017; Butler, Lewis 2002; Fileborn et al. 2015; Gott, Hinchliff 2003; Loe 2012; Roberts, Padgett-Yawn 2001; Walz 2002). 
In her later work, Jong considers tantric sex as a new way of lovemaking that is not linked to youthful sexual urges and the search for the desire for orgasm. Instead, it is wedded to a sense of intimacy and new understandings of sexual expressions in older adulthood (Stončikaite 2017). Rather than a problem, impotence becomes an opportunity to explore alternative ways of sex that make people grow closer to each other. The ageing protagonists in Fear of Dying discover kundalini, a physical energy that runs through the body like an electric serpent and grants new bodily sensations (Kumar, Larsen 2003; Jong 2015). The newly found whole-body experience through tantric sex teaches the couple that human sexuality, rather than sexual intercourse, is actually a mental state that allows them to experience a mutual flow of spiritual energy. As Jong's heroine Vanessa grows older, she places less importance on orgasmoriented experiences and youthful sexual urges: '[f]uck young and beautiful - this is worth everything - and I come with fierce contractions that seem to go on and endlessly' (Jong 2015: 213, emphasis in original). Instead of viewing sex as genital stimulation, Vanessa regards it as the power of mind and emotional fulfilment. In the novel, Jong argues that the process of ageing not only provides space to discover alternative sexual practices, but it also allows for a higher degree of intimacy and mutual understanding between partners, who become more confident when experimenting with sex in later years (Stončikaite 2017).

The author's later writings are also in line with research findings that reveal that men as they age focus less on the phallus and place more emphasis on foreplay, intimacy, closeness, and touch (Roberts, Padgett-Yawn 2001; Sandberg 2013; Wentzell 2013). Age-related sexual disabilities and the cessation of penetrative sex, instead of being regarded as a problem, often lead to the development of multifaceted understandings of human sexuality in older age (Sandberg 2013; Wentzell 2013). In her work, Jong shows that sexual pleasures can be lived through a different spectrum of sensual expressions, in which touch, tenderness, and closeness become the most important elements of sexual satisfaction in older age. In one of her interviews, conducted after the publication of Fear of Dying, the author stated that 'throughout our lives, from infancy to old age, we need touch. ... It's a lie that women shouldn't be touched when they're older. But it's another powerful aspect of sexist propaganda - that you're only fuckable if you're under 25 and pathologically underweight' (Abraham 2015: n/p). To Jong, human expressions of sexuality, closeness, and transcendence are synonymous since they help us to get closer to our inner being and attain a sense of spirituality and emotional intimacy.

Newly discovered sexual experiences also make Jong question heteronormative sex in later stages of life. In her later-life memoir Seducing the Demon (2006), Jong writes that as people grow older, heterosexuality loses its significance and individuals become freer than ever before to consider other forms of sex. According to Jong, since 
men die younger and tend to experience more health problems than women, older women have to contemplate alternative forms of sexual expression: 'heterosexual men grow scarce ..., but there are so many lovable women. Who knows what the future holds? I have learned never to say never' (2006: 95). Jong's arguments align with studies that demonstrate that growing older can sometimes bring out unusual swings in sexual orientation as post/menopausal women may discover a growing inclination towards lesbianism or bisexuality (Daniluk 2003; McCarn, Fassinger 1996; Weasel 1996). As Daniluk states, for many women 'it is not until midlife that they begin to be aware of and acknowledge the strength of their erotic desires toward women' (2003: 262). These observations again reveal that the interplay between ageing and sexuality is a complex one, and it becomes even more dynamic as we grow older. By offering alternative sexual narratives in her writings, Jong expresses her critical standpoint in terms of sexual optimisation in later life, the social construction of gender, ageism, and the successful ageing discourse. Additionally, she shows that human sexual expressions, like the experiences of growing older, are multifaceted and cannot be categorised.

\section{Conclusion}

Erica Jong's mid- and later-life writings reveal her self-evolution and alternative perspectives on the lingering gaps between feminism, gender, sexism, and ageism in two major areas: women's bodies and sexuality. On the one hand, Jong and her heroines attempt to erase the ravages of time with a facelift, even if it is the antithesis of the writer's call to redefine unattainable Western ideals of femininity. On the other hand, the author offers different ways of experiencing sexuality in later life that do not necessarily depend on intercourse and genital stimulation. Jong's works surpass the narrative of decline and the model of successful ageing by providing alternative views of old age that recreate a distinctive image of ageing women and especially the female representatives of the baby-boom generation in the United States. In her writings, the author invites her readers to rethink human sexuality in later years and argues that it is not bound to anti-ageing ideas. According to Jong, it can be focused on intimacy and emotional connection and that female liberation does not have to be premised on sexual inactivity. Jong also criticises heteronormative sexual practices as lacking the full potential of pleasure for both women and men. Instead, the writer goes on to suggest that women, as they age, may experience more freedom and feelings of uninhibited desires that help broaden their notions of sexuality to the point where gender per se becomes irrelevant.

Jong also expresses her deep-rooted concerns about the current feminist agenda and the ongoing double standard of ageing, which is especially visible on women's 
bodies and, in particular, their faces. The author shows how, despite the liberations and promises from the feminist movement of the 1970s and after, older women continue to struggle with the modern evolutions of ageism and sexism. Jong and her fictional characters find it hard to strike a balance between their youthful inner selves and their exterior appearance, which shows the powerful influence that socially constructed ideologies have. By allowing their bodies to be altered and reshaped, Jong and her heroines enact gendered roles, comply with expected feminine beauty ideals, and subject themselves to patriarchal anti-ageing discourses and capitalist profit.

Although juxtaposed with the many challenges facing ageing women today and with fading physical beauty, Erica Jong ultimately offers alternative representations of female ageing in her later works. Some of these positive aspects pertain to embracing oneself as an older woman in the purest manner possible in order to pursue a selfacceptance that is not marked by frailty, invisibility, or asexuality. The author contests the narrative of decline and the notion that older women's freedom and self-discovery is only possible through liberation from the patronising male gaze. By representing ageing heroines who try to challenge the double standard of ageing, the author seems to signal that later life may be a stage in life from which to explore alternative ways of pleasure-seeking and personal fulfilment and to take an active critical stand on sexism, gender inequality, and ageism.

This article has also attempted to show that literary representations of older age can help us to rethink the current constructions of ageing and provide us with new insights into what it means to grow older today. As Wyatt-Brown and Rossen note, 'to ignore that aspect of a writer's or character's life experience is to ignore a fundamental part of human nature' (1993: 1). Literary representations of old age contribute to a better understanding of gender relationships within feminist politics and help expand thinking beyond monolithic perceptions of ageing. In feminist thought, cultural and literary age studies appear to play a central role in reflections on age relations within the traditional feminist framework and in efforts to combat ageism, social inequalities, and the narrative of decline. In addition, feminist analysis not only applies to issues that concern women but is also relevant to men's studies and power and gender relations, among many other areas of study (Calasanti 2004, 2008). Ultimately, critical cultural and literary approaches to age, gender, and feminist studies can create space for broader discussions and can contribute to the ongoing development of dialogue in these disciplines. Hopefully, more positive representations of ageing women in popular culture and literature will gradually render older women more visible and decrease discrimination based on the female condition. Relatedly, they should make us more aware of the complexity of the reality of ageing, which involves more than just the biological processes and sociocultural constructs of growing older. 


\section{STATI / ARTICLES}

\section{References}

Abraham, A. 2015. Legendary Author Erica Jong on Ageing Gracefully. Refinery29.

Retrieved 10/1/2018 (www.refinery29.uk/2015/11/96698/erica-jong-author-womenageing-sex).

Althusser, L. 1971. Ideology and Ideological State Apparatuses. Pp. 121-176 in Monthly Review Press. Lenin and Philosophy and other Essays. Retrieved 21/3/2021 (https://www. marxists.org/reference/archive/althusser/1970/ideology.htm).

Baars, J. 2012. Ageing and the Art of Living. Baltimore, MD: Johns Hopkins University Press. Barry, E., M. Vibe Skagen. 2020. Introduction: The Difference That Time Makes. Pp. 1-15 in Barry, E., M. Vibe Skagen (eds.). Literature and Ageing. Cambridge: D. S. Brewer.

Bayer, K. 2005. Cosmetic Surgery and Cosmetics: Redefining the Appearance of Age. Generations: Journal of the American Society on Aging 29 (3): 13-18.

Berdychevsky, L., G. Nimrod. 2017. Sex as Leisure in Later Life: A Netnographic Approach. Leisure Sciences 39 (3): 224-243.

Berger, P., T. Luckman. 1991. The Social Construction of Reality: A Treatise in the Sociology of Knowledge. London: Penguin Books.

Blaikie, A. 1999. Aging and Popular Culture. Cambridge: Cambridge University Press.

Burns, C. 2015. Erica Jong is Back - As Fearless as Ever. The Washington Post. Retrieved 11/1/2017 (www.washingtonpost.com/entertainment/books/erica-jong-is-back--asfearless-as-ever/2015/09/08/2dd30a18-55d7-11e5-b8c9-944725fcd3b9_story.html).

Butler, J. 1990. Gender Trouble: Feminism and the Subversion of Identity. London: Routledge.

Butler, R., M. I. Lewis. 2002. The New Love and Sex After 60. New York: Random House Publishing Group.

Calasanti, T. M. 2004. New Directions in Feminist Gerontology: An Introduction. Journal of Aging Studies 18 (1): 1-8.

Calasanti, T. M. 2008. A Feminist Confronts Ageism. Journal of Aging Studies 22 (2): 152-157.

Calasanti, T. M. 2016. Combating Ageism: How Successful Is Successful Aging? The Gerontologist 56 (6): 1093-1101.

Calasanti, T. M., K. F. Slevin. 2001. Gender, Social Inequalities, and Aging. Walnut Creek, CA: AltaMira Press.

Calasanti, T. M., N. King. 2005. Firming the Floppy Penis: Class and Gender Relations in the Lives of Old Men. Men and Masculinities 8 (1): 3-23.

Calasanti, T. M., N. King. 2007. 'Beware of the Estrogen Assault': Ideals of Old Manhood in Anti-aging Advertisements. Journal of Aging Studies 21 (4): 357-368.

Calasanti, T. M., N. King. 2015. Intersectionality and Age. Pp. 193-201 in Twigg, J., W. Martin (eds.). Routledge Handbook of Cultural Gerontology. London: Routledge.

Casado-Gual, N., E. Domínguez, B. J. Worsfold (eds.). 2016. Literary Creativity and the Older Woman Writer: A Collection of Critical Essays. Bern: Peter Lang.

Cohen-Shalev, A. 2008. Sailing on Seas of Uncertainties: Late Style and Puccini's Struggle for Self-renewal. International Journal of Ageing and Later Life 3 (1): 77-95.

Daniluk, J. C. 2003. Women's Sexuality Across the Life Span: Challenging Myths, Creating 
Meanings. New York: The Guilford Press.

de Beauvoir, S. 1996. The Coming of Age. New York: Norton.

de Medeiros, K. 2016. The Short Guide to Aging and Gerontology. Bristol: Policy Press.

Farshidfar, Z., R. Dastjerdi, F. Shahabizadeh. 2013. Acceptance of Cosmetic Surgery: Body Image, Self Esteem and Conformity. Procedia - Social and Behavioral Sciences 84 (9): 238-242.

Featherstone, M., M. Hepworth. 1989. Aging and Old Age: Reflections on the Post-

Modern Life Course. Pp. 143-157 in Bytheway, B., T. Keil, P. Allat, A. Bryman (eds.). Being and Becoming Old: Sociological Approaches To Later Life. Newbury Park: Sage.

Featherstone, M., M. Hepworth. 1999. The Mask of Aging and the Postmodern Life Course.

Pp. 371-389 in Feathersone, M., M. Hepworth, B. Turner (eds.). The Body: Social and Cultural Theory. London: Sage.

Fileborn, B., R. Thorpe, G. Hawkes, V. Minichiello, M. Pitts, T. Dune. 2015. Sex, Desire and Pleasure: Considering the Experiences of Older Australian Women. Sexual and Relationship Therapy 30 (1): 117-130.

Friedan, B. 1993. The Fountain of Age. London: Vintage.

Gilleard, C., P. Higgs. 2014. Aging, Corporeality and Embodiment. London: Anthem Press.

Gott, M., S. Hinchliff. 2003. How Important Is Sex in Later Life? The Views of Older People. Social Science \& Medicine 56 (8): 1617-1628.

Greer, G. 1991. The Change: Women, Ageing and the Menopause. London: Hamish Hamilton.

Gullette, M. M. 2004. Aged by Culture. Chicago, IL: Chicago University Press.

Gullette, M. M. 2011. Agewise: Fighting the New Ageism in America. Chicago, IL: Chicago University Press.

Heilbrun, C. 1991. Naming A New Rite of Passage. Smith Alumnae Quarterly (Summer): 26-28.

Henderson-King, D., E. Henderson-King. 2005. Acceptance of Cosmetic Surgery: Scale Development and Validation. Body Image 2 (2): 137-149.

Hepworth, M. 2000. Stories of Aging. Buckingham: Open University.

Jong, E. 1994. Fear of Fifty, A Mid-Life Memoir. New York: Harper Collins Publishers.

Jong, E. 1999. What Do Women Want? Bread, Roses, Sex, Power. London: Bloomsbury.

Jong, E. 2006. Seducing the Demon: Writing for My Life. New York: Penguin.

Jong, E. 2015. Fear of Dying. New York: St. Martin's Press.

Katz, S. 1996. Disciplining Old Age: The Formation of Gerontological Knowledge.

Charlottesville, VA: University Press of Virginia.

Katz, S. 2000. Busy Bodies: Activity, Aging and the Management of Everyday Life. Journal of Aging Studies 14 (2): 135-152.

Katz, S., B. L. Marshall. 2003. New Sex for Old: Lifestyle, Consumerism, and the Ethics of Aging Well. Journal of Aging Studies 17 (1): 3-16.

Katz, S., J. Gish. 2015. Aging in the Biosocial Order: Repairing Time and Cosmetic Rejuvenation in a Medical Spa Clinic. The Sociological Quarterly 56: 40-61.

Katz, S., T. M. Calasanti. 2015. Critical Perspectives on Successful Aging: Does It 'Appeal More Than It Illuminates'? The Gerontologist 55 (1): 26-33. 


\section{STATI / ARTICLES}

King, J. 2013. Discourses of Aging in Fiction and Feminism: The Invisible Woman. Basingstoke: Palgrave Macmillan.

Kriebernegg, U. 2015. Literary Gerontology: Understanding Aging as a Lifelong Process through Cultural Representation. The Gerontologist 55 (Issue Suppl. 2): 839.

Kumar, R., J. Larsen. 2003. Secrets of Kundalini Awakening: Life after Death and Quantum Soul. New Delhi: Publishers Pvt. Ltd.

Laliberte, D. R. 2015. Embodying Positive Aging and Neoliberal Rationality: Talking About the Aging Body within Narratives of Retirement. Journal of Aging Studies 34: 10-20.

Loe, M. 2012. Pleasure in Old Age. Pp. 278-295 in Carpenter, L. M., J. De Lamater (eds.). Sex for Life: From Virginity to Viagra, How Sexuality Changes throughout Our Lives. New York: New York University Press.

Marshall, B. L., S. Katz. 2012. The Embodied Life Course: Post-Ageism or the Renaturalization of Gender? Societies 2 (4): 222-234.

Martinson, M., C, Berridge. 2015. Successful Aging and Its Discontents: A Systematic Review of the Social Gerontology Literature. The Gerontologist 55 (1): 58-69.

McCarn, R. S., R. E. Fassinger. 1996. Revisioning Sexual Minority Identity Formation: A New Model of Lesbian Identity and Its Implications for Counseling and Research. Counselling Physiologist 24 (3): 508-534.

Mykytyn, E. C. 2006. Anti-Aging Medicine: A Patient/Practitioner Movement to Redefine Aging. Social Science \& Medicine 62 (3): 643-653.

Öberg, P. 2003. Images versus Experience of the Aging Body. Pp. 103-132 in Faircloth, C. A. (ed.). Aging Bodies: Images and Everyday Experience. Walnut Creek, CA: AltaMira Press.

Roberts, A., B. Padgett-Yawn (eds.). 2001. Reader's Digest Guide to Love and Sex. London: The Reader's Digest Association Limited, DL.

Rowe J., R. Kahn. 1987. Human Ageing: Usual and Successful. Science 237 (4811): 143-149.

Rowe, J., R. Kahn. 1998. Successful Aging. New York: Pantheon Books.

Sandberg, L. 2013. Affirmative Old Age: The Aging body and Feminist Theories on

Difference. International Journal of Aging \& Later Life 8 (1): 11-40.

Sandberg, L. 2015. Sex, Sexuality, and Later Life. Pp. 218-226 in Twigg, J., W. Martin (eds.). Routledge Handbook of Cultural Gerontology. London: Routledge.

Sandberg, L., B. L. Marshall. 2017. Queering Aging Futures. Societies 7 (3): 21.

Smirnova, M. H. 2012. A Will to Youth: The Woman's Anti-Aging Elixir. Social Science \& Medicine 75 (7): 1236-1243.

Sontag, S. 1972. The Double Standard of Aging. The Saturday Review, 23 September: 29-38.

Stončikaitè, I. 2017. 'No, My Husband Isn't Dead, [But] One Has to Re-Invent Sexuality':

Reading Erica Jong for the Future of Aging. Societies 7 (2): 11.

Stončikaitè, I. 2019. Critical Approaches to Ageing Body Politics in the Works of Erica Jong. Societies 9 (2): 47.

Stončikaitè, I. 2020. To Lift or Not to Lift? The Dilemma of an Aging Face in Erica Jong's Later Works. Journal of Aging Studies 52: 1-7.

Strawbridge, J., M. I. Wallhagen. 2002. Successful Aging and Well-Being: Self-Rated Compared with Rowe and Kahn. The Gerontologist 42 (6): 727-733.

Templin, A. C. (ed.). 1995. Feminism and the Politics of Literary Reputation. The Example of 
Erica Jong. Lawrence: University Press of Kansas.

Templin, A. C. (ed.). 2002. Conversations with Erica Jong. Jackson, MS: University Press of Mississippi.

Timonen, V. 2016. Beyond Successful and Active Ageing: A Theory of Model Ageing. Bristol: Policy Press Shorts Research.

Twigg, J., W. Martin (eds.). 2015. Routledge Handbook of Cultural Gerontology. London and New York: Routledge.

Vincent, J. A. 2008. The Cultural Construction Old Age as a Biological Phenomenon: Science and Anti-Ageing Technologies. Journal of Aging Studies 22 (4): 331-339.

Vincent, J. A., C. Phillipson, M. Downs (eds.). 2006. The Futures of Old Age. Thousand Oaks, CA: Sage.

Walz, T. 2002. Crones, Dirty Old Men, Sexy Seniors: Representations of the Sexuality of Older Persons. Journal of Aging and Identity 7: 99-112.

Waxman, B. F. 1990. From the Hearth to the Open Road: A Feminist Study of Aging in Contemporary Literature. New York: Greenwood Press.

Weasel, H. L. 1996. Seeing Between the Lines: Bisexual Women and Therapy. Women and Therapy 19 (2): 5-16.

Wentzell, E. A. 2013. Maturing Masculinities: Aging, Chronic Illness, and Viagra in Mexico. Durham, NC: Duke University Press.

WHO. 2018. Ageing and Health. Retrieved 21/3/2021 (https://www.who.int/news-room/ fact-sheets/detail/ageing-and-health).

Wolf, N. 2002. The Beauty Myth: How Images of Beauty Are Used against Women. New York: Harper and Row.

Woodward, M. K. 1999. Inventing Generational Models: Psychoanalysis, Feminism, Literature. Pp. 149-171 in Woodward, M. K. (ed.). Figuring Age: Women, Bodies, Generations. Bloomington, IN: Indiana University Press.

Wyatt-Brown, M. A. 2010. Resilience and Creativity in Aging: The Realms of Silver. Pp. 57-83 in Cole, T. R., R. E. Ray, R. Kastenbaum (eds.). A Guide to Humanistic Studies of Aging: What Does It Mean to Grow Old? Baltimore, MD: Johns Hopkins University Press. Wyatt-Brown, M. A., J. Rossen (eds.). 1993. Aging and Gender in Literature: Studies in Creativity. Charlottesville, VA: University Press of Virginia.

Zeilig, H. 2011. The Critical Use of Narrative and Literature in Gerontology. International Journal of Ageing and Later Life 6 (2): 7-37.

(c) BY-NC leva Stončikaitè, 2021.

BY-NC Institute of Sociology of the Czech Academy of Sciences, 2021.

leva Stončikaitè, PhD, is an adjunct lecturer in Comparative Literature at the Department of English and Linguistics of the University of Lleida (Spain). She has presented her research in conferences and scholarly journals, such as The Gerontologist, Journal of Aging Studies, and Life Writing. leva is interested in interdisciplinary age studies with a special focus on later-life creativity, cultural/literary gerontology, senior leisure tourism, and arts-based research on ageing. Contact e-mail: iewukaz@yahoo.com. 